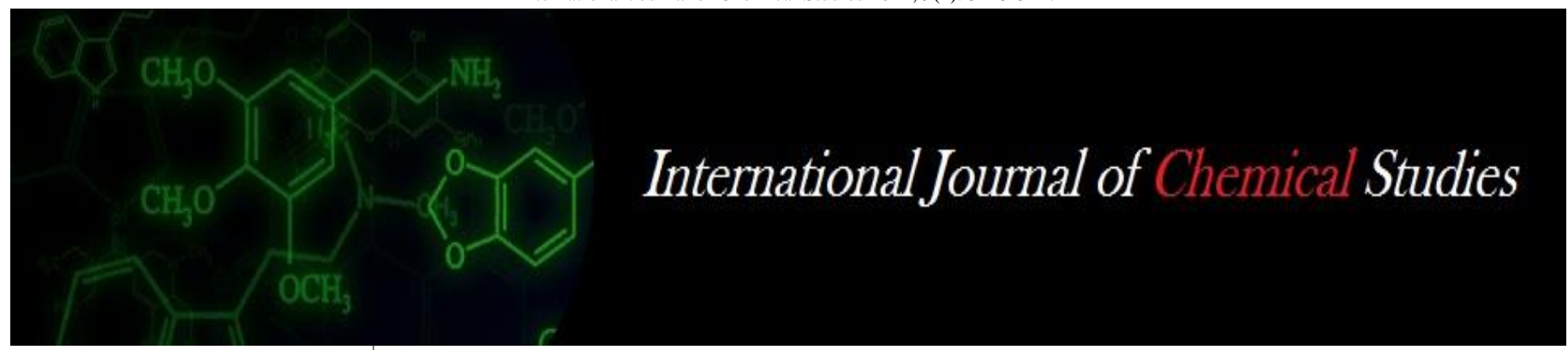

P-ISSN: 2349-8528

E-ISSN: 2321-4902

www.chemijournal.com

IJCS 2021; 9(1): 3423-3427

(C) 2021 IJCS

Received: 23-11-2020

Accepted: 30-12-2020

Raghavendra HR

Centre of Excellence on PHT

ASPEE, College of Horticulture

and Forestry, Navsari

Agricultural University,

Navsari, Gujarat, India

\section{Desai Chirag}

Assistant Research Scientist

(PHT), Soil and Water

Management Research Unit,

Navsari Agricultural University,

Navsari, Gujarat, India

\section{Madhusudan Ravikumar}

Centre of Excellence on PHT,

ASPEE College of Horticulture

and Forestry, Navsari

Agricultural University, Navsari,

Gujarat, India

\section{Hari Vaidya}

Soil and Water Management

Research Unit, Navsari

Agricultural University, Navsari,

Gujarat, India
Corresponding Author:

Raghavendra HR

Centre of Excellence on PHT

ASPEE, College of Horticulture

and Forestry, Navsari

Agricultural University,

Navsari, Gujarat, India

\section{Effect of blending proportion on sensory appeal of banana fruit (Musa paradisiaca $L$.) and pseudostem central core blended jam}

\author{
Raghavendra HR, Desai Chirag, Madhusudan Ravikumar and Hari \\ Vaidya
}

DOI: $\underline{\text { https://doi.org/10.22271/chemi.2021.v9.i1av.11765 }}$

\begin{abstract}
The present investigation entitled "Effect of blending proportion on sensory appeal of banana fruit (Musa paradisiaca L.) and pseudostem central core blended jam" deals with the preparation of jam using combinations of banana fruit and pseudostem central core pulp as per treatments which were packed in glass bottles and stored at ambient temperature which were analyzed for sensory acceptance from the trained and non-trained people. The jams were studied at an interval of two months upto 6 months of storage period which was statistically analysed using completely randomized design. It can be elucidated that sensory evaluation of blended jam i.e. treatment with banana: pseudostem central core gained maximum acceptance score of colour and taste at initial, 3 and 6 months of storage which might be due to higher proportion of banana pulp which was preferred more by sensory panellists. Overall findings of investigation revealed that blended jam bottles can be successfully stored for 6 months with minimum changes in chemical and sensory qualities. Moreover, blending up to 50\% banana pseudostem central core pulp with $50 \%$ banana pulp were found with acceptable sensory qualities which not only gives good sensory characters but provide higher nutritive qualities i.e. iron, potassium, fiber and lipid value to the product.
\end{abstract}

Keywords: Banana, pseudostem, blended, storage, sensory

\section{Introduction}

Banana is one of the oldest fruit crops which were mentioned earlier in the epics of Ramayana (2020 BC) and Kautilya's Arthashastra (300-400 BC). It is the cheapest, plentiful and most nutritive fruit which is having great economic significance in India (Radha and Mathew, 2007) [1]. Many researches findings showed that banana fruit as one of the man's first food. It is deeply interwoven with the Indian cultural heritage that its leaves, pseudostem and fruits are considered very auspicious in all celebrations of the festivals. It is an important source of fibre, fodder, food, beverages, fermented sugars, medicines, flavorings, silage, rope, cordage, garlands, shelter, clothing, making house roofs and wall linings. By considering all these multifaceted uses, it is referred as Kalpatharu.

Banana is considered as nutritionally significant fruit which provides balanced diet than any other fruit. The raw fruit consumed after cooking is called as plantain banana and fruit eaten after ripening is referred as dessert banana. The nutritive components of banana are very close to that of potato, but compared to potato it has energy per $100 \mathrm{~g}$ is higher. Even when compare to apple, one banana has four times the proteins, twice the carbohydrates, three times the phosphorous, five times the vitamins and iron (Nakirya, 2007) ${ }^{[2]}$. The high sugar content in a ripe banana supplies almost double the energy of an apple and nearly three times that of citrus fruits.

As nutritional diet is considered, banana is highly satisfying, easy to digest, fat free, rich source of carbohydrate with calorific value of 67-137 KJ per $100 \mathrm{~g}$ of edible part. Due to free from sodium which makes a salt free diet suitable to all age groups and people of all levels. The composition of banana fruit per $100 \mathrm{~g}$ of edible portion are water 75 per cent, protein 1.1 per cent, fat 0.2 per cent and carbohydrate 12.6 per cent. The mineral contents are calcium 8 $\mathrm{mg}$, phosphorus $26 \mathrm{mg}$, iron $0.7 \mathrm{mg}$ and ascorbic acid $10 \mathrm{mg}$ (Chundawat and Sen, 2002) ${ }^{[3]}$. In Gujarat, area under total fruit crops is 392.95 thousand hectare and production is 8482.80 
thousand MT. Out of this banana occupies 64.7 thousand hectare area with production of 4185.52 thousand MT (Anonymous, 2017) ${ }^{[5]}$. The major cultivars grown in Gujarat region are Dwarf Cavendish, Lacatan, Harichal, Grand Naine and Gandevi Selection [Patel and Naik (2013)] ${ }^{[14]}$.

In India, post harvest losses in banana are estimated to be 3040 per cent (Salunkhe and Desai, 1984) ${ }^{[6]}$ and about 60-70 per cent losses occur during ripening of fruits. The potential marketing period (PMP) of 14 days is very short therefore fruit needs to be processed into variety of products that can extend the availability and marketing period of fruits. In India, less than 2.4 per cent of fruits and vegetables are being processed as compared to other countries. It is necessary that fruit must be preserved, so that wastage can be minimized and increased production can be properly managed and utilized. We can reduce losses and increase the income of farmers through proper post harvest management.

It is reported that instead of single fruit products, the blended products with two or more fruits are preferred by consumers. The major advantages of blended products are increasing the qualitative, sensory and nutritional value of the product. Moreover, there is always demand from consumers all over the world for new and blended product, which may be nutritious and pleasant flavored. Hence, it is decided to blend pulp of banana with banana pseudostem central core pulp to standardize the recipe for jam. The pseudostem is the part, which contains dietary fibre and $90 \%$ moisture, which increase dietary fibre intake in the body. Keeping in view of the wastage of banana pseudostem in plantations, the present study was aimed to convert the fresh banana pseudostem central core into jam by blending with ripe banana fruits.

\section{Materials and Methods}

The experiment was taken at the laboratories of Post Harvest Technology laboratory, N.A.U., Navsari. Based on days from flowering and changing fruit colour from dark green to pale green or yellowish green, full three quarter level matured, uniform sized banana fruits of $c v$. Grand Naine were taken from the field of Soil and Water Management Research Unit, Navsari Agricultural University, Navsari and brought to the laboratory for experimentation in the first week of February. The banana pseudostem were washed and cleaned. These pseudostems were hygienically used for product processing in experiment. Pseudostem were split by sharp stainless steel knife and the central core were sliced into thin pieces using slicer and utilized to extract the pulp using fruit pulper.

Blended jam was prepared from the pulp of banana fruits pulp and banana pseudostem central core pulp. Total 11 treatments were used for preparation of jam using different blending proportion of banana fruits and pseudostem central core pulp. The acidity and TSS of the jam was kept constant $0.5 \%$ and $68 \%$, respectively in all the treatments (Table 1 ). The blended jam was periodically observed up to 6 months i.e. February 2018 to July 2018. The samples were subsequently used for organoleptic evaluation for 0,3 and 6 months of storage. The jam was stored in wide mouth glass jar of $200 \mathrm{~g}$ capacity. The packed bottles were kept in darkened, cool and dry place at room temperature which ranged from 20 to $35^{\circ} \mathrm{C}$ temperatures.

\section{a. Methodology adopted for recording the organoleptic parameters (adopted 9 point hedonic scale)}

Sensory evaluation of blended jam was conducted during storage to assess the consumer's acceptance for the product. The prepared samples were evaluated for sensory qualities on the basis of colour, texture, taste, flavour and overall acceptability on a 9 point hedonic scale. For the accurate results, a panel of faculty members and PG students of Department of Post Harvest Technology, NAU, Navsari were used for sensory analysis throughout the storage period interval. A taste breaker like murmura with normal tap water was provided to the panellists for mouth rinsing in between the sensory test.

Table 1: Treatment details under study

\begin{tabular}{|c|c|c|c|c|c|}
\hline Treatments & Blending ratio (banana fruit: central core) & Pulp: sugar ratio & TSS $\left({ }^{0} \mathbf{B}\right)$ & Acidity (\%) & Pectin \\
\hline $\mathrm{T}_{1}$ & $0: 100$ & $1: 1$ & 68 & 0.5 & 0.75 \\
\hline $\mathrm{T}_{2}$ & $10: 90$ & $1: 1$ & 68 & 0.5 & 0.75 \\
\hline $\mathrm{T}_{3}$ & 20:80 & $1: 1$ & 68 & 0.5 & 0.75 \\
\hline $\mathrm{T}_{4}$ & $30: 70$ & $1: 1$ & 68 & 0.5 & 0.75 \\
\hline $\mathrm{T}_{5}$ & $40: 60$ & $1: 1$ & 68 & 0.5 & 0.75 \\
\hline $\mathrm{T}_{6}$ & 50:50 & $1: 1$ & 68 & 0.5 & 0.75 \\
\hline $\mathrm{T}_{7}$ & $60: 40$ & $1: 1$ & 68 & 0.5 & 0.75 \\
\hline $\mathrm{T}_{8}$ & $70: 30$ & $1: 1$ & 68 & 0.5 & 0.75 \\
\hline $\mathrm{T}_{9}$ & $80: 20$ & $1: 1$ & 68 & 0.5 & 0.75 \\
\hline $\mathrm{T}_{10}$ & $90: 10$ & $1: 1$ & 68 & 0.5 & 0.75 \\
\hline $\mathrm{T}_{11}$ & $100: 0$ & $1: 1$ & 68 & 0.5 & 0.75 \\
\hline
\end{tabular}

Experimental Results and Discussion

a. Initial physical and chemical status of banana cv. Grand Naine fruit and pseudostem central core

Looking into the table 2 , it is noted that pulp recovery of banana fruit was $55.9 \%$ whereas the central core showed pulp recovery of $75 \%$. The average weight of the banana fruits (per hands) was $2112.9 \mathrm{~g}$ and the peel weight and pulp weight was $931.95 \mathrm{~g}$ and $1180.95 \mathrm{~g}$ respectively. The average weight of central core (per $1 \mathrm{ft}$. core) was $680.00 \mathrm{~g}$ whereas outer layer weight and pulp weight was $170.00 \mathrm{~g}$ and $510.00 \mathrm{~g}$ respectively. By looking towards the table 3 , it was indicated that total soluble solids content of banana fruit was 21.400Brix while pseudostem central core has TSS of 20Brix. The acidity content of banana fruit was 0.412 per cent whereas pseudostem central core showed acidity content of 0.19 per cent.

Table 2: Physical parameters of fresh fruit of banana cv. Grand Naine pseudostem central core

\begin{tabular}{|c|c|c|c|}
\hline $\begin{array}{c}\text { Sr. } \\
\text { No. }\end{array}$ & Characters & $\begin{array}{c}\text { Banana cv. Grand Naine (per } \\
\text { hands) }\end{array}$ & $\begin{array}{c}\text { Pseudostem central core(*) } \\
\text { (per 1 ft. core) }\end{array}$ \\
\hline 1. & Average weight of fruits $(\mathrm{g}) *$ central core weight $(\mathrm{g})$ & 2112.9 & 680.00 \\
\hline
\end{tabular}




\begin{tabular}{|c|c|c|c|}
\hline 2. & Peel weight of banana fruit $(\mathrm{g})$ *outer pseudostem layer weight $(\mathrm{g})$ & 931.95 & 170.00 \\
\hline 3. & Pulp weight of fruits $(\mathrm{g}) *$ central core pulp $(\mathrm{g})$ & 1180.95 & 510.00 \\
\hline 4 & Pulp recovery $(\%)$ & 55.9 & 75 \\
\hline
\end{tabular}

Table 3: Chemical composition of fresh fruit of banana cv. Grand Naine pseudostem central core

\begin{tabular}{|c|c|c|c|}
\hline Sr. No. & Characters' & Banana cv. Grand Naine & Pseudostem central core \\
\hline 1. & Total soluble solids $\left({ }^{0} \mathrm{~B}\right)$ & 21.40 & 2 \\
\hline 2. & Acidity $(\%)$ & 0.412 & 0.19 \\
\hline
\end{tabular}

\section{b. Sensory changes of banana fruit and pseudostem central core blended jam during storage \\ 1. Colour (out of 9 points)}

Data regarding the changes in colour acceptability of blended jam as various combinations of banana fruit and pseudostem central core have been presented in the Table 4. Observations revealed that, at initial stage organoleptic quality status in respect of colour of blended jam, the maximum score value was found in the treatment $T_{11}$ (8.05) (banana fruit: pseudostem central core 100:00) followed by $\mathrm{T}_{10}$ (7.98) (banana fruit: pseudostem central core 90:10). However, $\mathrm{T}_{1}$ combination of blended jam recorded lowest colour score value (6.32) (banana fruit: pseudostem central core 00:100) followed by $\mathrm{T}_{2}$ (6.54) (banana fruit: pseudostem central core 10:90).

At 3 month storage, maximum colour value was observed in the treatment $T_{11}$ (8.02) which were followed by $T_{10}$ (7.69). However, the lowest colour score value was recorded in the treatment $T_{1}(6.12)$ followed by $T_{2}(6.49)$. The treatment $T_{11}$ combination of blended jam recorded the maximum colour value (8.01) followed by $\mathrm{T}_{10}$ (7.49). Lowest colour value was recorded in the treatment $T_{1}$ (6.0) which was followed by $T_{2}$ (6.32) during 6th month of storage. It showed decreasing trend during 6 months of storage period.

The colour score of the product was decreased significantly during storage up to 6 months. It might be due to non enzymatic browning and oxidation of phenolic compounds. The maximum colour score was obtained in $\mathrm{T}_{11}$ which may be due to have bright brown colour which was preferred more by panelists. Lowest colour was found in $T_{1}$ due to colourless and lightly transparent. During storage higher colour score remained highest in mean value as well as lower colour score remained lowest in mean value. However colour score was found acceptable i.e. above 7.00 up to blending of $50 \%$ pseudostem central core pulp with $50 \%$ banana pulp. These findings were in accordance with results obtained by Shakir et al. (2008) ${ }^{[7]}$ in apple and pear mixed fruit jam, Chanbisana and Banik (2014) ${ }^{[8]}$ in ripe banana jam, Deep Shika Sharma (2014) ${ }^{[9]}$ in mango-jamun blended jam. Similarly Anon. (2015) also found the similar results in pseudostem central core jam.

\section{Texture (out of 9 points)}

Data on sensory evaluation in respect of texture value have been presented in Table 5. Observations revealed that, at initial stage organoleptic quality status in respect of texture of blended jam, the maximum score value was found in the treatment $\mathrm{T}_{11}$ (8.36) (banana fruit: pseudostem central core 100:00) followed by $\mathrm{T}_{10}$ (8.04) (banana fruit: pseudostem central core 90:10). However, $\mathrm{T}_{1}$ combination of blended jam recorded lowest texture score value (6.56) (banana fruit: pseudostem central core 00:100) followed by $\mathrm{T}_{2}$ (6.72) (banana fruit: pseudostem central core 10:90).

At 3 month storage, maximum texture value was observed in the treatment $T_{11}$ (8.27) which were followed by $T_{10}$ (8.02). However, the lowest texture score value was recorded in the treatment $T_{1}$ (6.49) followed by $T_{2}(6.68)$. The treatment $T_{11}$ combination of blended jam recorded the maximum texture value (8.19) followed by $\mathrm{T}_{10}(8.00)$. Lowest texture value was recorded in the treatment $T_{1}(6.47)$ which was followed by $T_{2}$ (6.62) during 6th month of storage. It showed decreasing trend during 6 months of storage period.

The maximum texture score was obtained in $T_{11}$ which may be due to juicy and loose texture which was preferred more by panelists. Lowest texture was found in $\mathrm{T}_{1}$ due to hard texture and more fiber. The texture score of the product was decreased significantly during storage up to 6 months. This pattern of decline of texture score during storage might be due to the adverse effect of atmospheric temperature and moisture. However texture score was found acceptable i.e. above 7.00 up to blending of $50 \%$ pseudostem central core pulp with $50 \%$ banana pulp. These findings were in accordance with results obtained by Shakir et al. (2008) ${ }^{[7]}$ in apple and pear mixed fruit jam, Vikram et al. (2012) ${ }^{[10]}$ in amla jam with granulated particles of coconut. Deep Shika Sharma (2014) ${ }^{[9]}$ also found decreased trend in texture value in mango-jamun blended jam. Similarly Haqa and Darakshamb (2014) ${ }^{[8]}$ also found the similar results in dried apricot-date blended jam.

\section{Taste (out of 9 points)}

Data regarding the changes in taste acceptability of banana fruit and pseudostem central core blended jam was influenced by various treatments during the storage have been presented in Table 6. Initially (at 0 month), maximum acceptable taste value was found in the treatment $T_{11}$ (8.36) (banana fruit: pseudostem central core 100:00) followed by $\mathrm{T}_{10}$ (8.01) (banana fruit: pseudostem central core 90:10). The least taste score value was noted in the treatment $T_{1}(6.39)$ (banana fruit: pseudostem central core 00:100) followed by $\mathrm{T}_{2}$ (6.58) (banana fruit: pseudostem central core 10:90).

After 3 month of storage, treatment $T_{11}$ was found to be highest taste score value (8.23) followed by $\mathrm{T}_{10}(8.00)$. The lowest taste score value was noted in the treatment $\mathrm{T}_{1}(6.31)$ followed by $T_{2}$ (6.43). The treatment $T_{11}$ combination of blended jam recorded the maximum taste score value (8.19) followed by $\mathrm{T}_{10}$ (7.98). Lowest taste score value was recorded in the treatment $T_{1}(6.29)$ which was followed by $T_{2}(6.41)$ during 6th month of storage. It showed decreasing trend during 6 months of storage period.

Moreover, the highest taste score was found in $\mathrm{T}_{11}$ which may be due to sweet in taste compare to sole central core jam $T_{1}$. The taste score of the product was decreased significantly irrespective of the treatment by end of the 6 months during storage. This pattern of decline of taste score during storage might be due to the adverse effect of atmospheric moisture and the biochemical changes during storage. However taste score was found acceptable i.e. above 7.00 up to blending of $50 \%$ pseudostem central core pulp with $50 \%$ banana pulp. Similar observations were also made by Vikram et al. (2012) [10] in amla jam with granulated particles of coconut. Deep Shika Sharma (2014) ${ }^{[9]}$ also found decreased trend in taste 
value in mango-jamun blended jam. Similarly Haqa and Darakshamb (2014) ${ }^{[8]}$ also found the similar results in dried apricot-date blended jam.

Table 4: Effect of banana fruit and pseudostem central core blended jam on colour during storage

\begin{tabular}{|c|c|c|c|c|}
\hline \multirow{2}{*}{ Treatments } & \multicolumn{3}{|c|}{ Storage period (P) } & \multirow{2}{*}{ Mean (T) } \\
\cline { 2 - 4 } & $\mathbf{P}_{\mathbf{1}}$ (Initial) & $\mathbf{P}_{\mathbf{2}}$ (3 month) & $\mathbf{P}_{\mathbf{3}}$ (6 month) & \\
\hline $\mathrm{T}_{1}$ & 6.32 & 6.12 & 6.00 & 6.15 \\
\hline $\mathrm{T}_{2}$ & 6.54 & 6.49 & 6.32 & 6.45 \\
\hline $\mathrm{T}_{3}$ & 6.72 & 6.58 & 6.49 & 6.60 \\
\hline $\mathrm{T}_{4}$ & 6.89 & 6.75 & 6.72 & 6.79 \\
\hline $\mathrm{T}_{5}$ & 6.93 & 6.86 & 6.79 & 6.86 \\
\hline $\mathrm{T}_{6}$ & 7.03 & 7.00 & 6.98 & 7.00 \\
\hline $\mathrm{T}_{7}$ & 7.07 & 7.01 & 7.00 & 7.03 \\
\hline $\mathrm{T}_{8}$ & 7.35 & 7.33 & 7.23 & 7.30 \\
\hline $\mathrm{T}_{9}$ & 7.56 & 7.48 & 7.37 & 7.47 \\
\hline $\mathrm{T}_{10}$ & 7.98 & 7.69 & 7.49 & 7.72 \\
\hline $\mathrm{T}_{11}$ & 8.05 & 8.02 & 8.01 & 8.03 \\
\hline
\end{tabular}

Table 5: Effect of banana fruit and pseudostem central core blended jam on texture during storage

\begin{tabular}{|c|c|c|c|c|}
\hline \multirow{2}{*}{ Treatments } & \multicolumn{3}{|c|}{ Storage period (P) } & \multirow{2}{*}{ Mean (T) } \\
\cline { 2 - 5 } & $\mathbf{P}_{\mathbf{1}}$ (Initial) & $\mathbf{P}_{\mathbf{2}}$ (3 month) & $\mathbf{P}_{\mathbf{3}}$ (6 month) & \\
\hline $\mathrm{T}_{1}$ & 6.56 & 6.49 & 6.47 & 6.51 \\
\hline $\mathrm{T}_{2}$ & 6.72 & 6.68 & 6.62 & 6.67 \\
\hline $\mathrm{T}_{3}$ & 6.79 & 6.73 & 6.69 & 6.74 \\
\hline $\mathrm{T}_{4}$ & 6.83 & 6.79 & 6.78 & 6.80 \\
\hline $\mathrm{T}_{5}$ & 6.93 & 6.89 & 6.79 & 6.87 \\
\hline $\mathrm{T}_{6}$ & 7.21 & 7.16 & 7.14 & 7.17 \\
\hline $\mathrm{T}_{7}$ & 7.36 & 7.29 & 7.23 & 7.29 \\
\hline $\mathrm{T}_{8}$ & 7.52 & 7.43 & 7.41 & 7.45 \\
\hline $\mathrm{T}_{9}$ & 7.69 & 7.58 & 7.53 & 7.60 \\
\hline $\mathrm{T}_{10}$ & 8.04 & 8.02 & 8.00 & 8.02 \\
\hline $\mathrm{T}_{11}$ & 8.36 & 8.27 & 8.19 & 8.27 \\
\hline \multicolumn{4}{|r}{}
\end{tabular}

Table 6: Effect of banana fruit and pseudostem central core blended jam on texture during storage

\begin{tabular}{|c|c|c|c|c|}
\hline \multirow{2}{*}{ Treatments } & \multicolumn{3}{|c|}{ Storage periods (P) } & \multirow{2}{*}{ Mean (T) } \\
\cline { 2 - 4 } & $\mathbf{P}_{\mathbf{1}}$ (Initial) & $\mathbf{P}_{\mathbf{2}}$ (3 month) & $\mathbf{P}_{\mathbf{3}}(\mathbf{6}$ month) & \\
\hline $\mathrm{T}_{1}$ & 6.39 & 6.31 & 6.29 & 6.33 \\
\hline $\mathrm{T}_{2}$ & 6.58 & 6.43 & 6.41 & 6.47 \\
\hline $\mathrm{T}_{3}$ & 6.74 & 6.69 & 6.53 & 6.65 \\
\hline $\mathrm{T}_{4}$ & 6.87 & 6.81 & 6.79 & 6.82 \\
\hline $\mathrm{T}_{5}$ & 6.98 & 6.86 & 6.83 & 6.89 \\
\hline $\mathrm{T}_{6}$ & 7.32 & 7.30 & 7.26 & 7.29 \\
\hline $\mathrm{T}_{7}$ & 7.56 & 7.49 & 7.46 & 7.50 \\
\hline $\mathrm{T}_{8}$ & 7.68 & 7.62 & 7.59 & 7.63 \\
\hline $\mathrm{T}_{9}$ & 7.89 & 7.76 & 7.68 & 7.78 \\
\hline $\mathrm{T}_{10}$ & 8.01 & 8.00 & 7.98 & 8.00 \\
\hline $\mathrm{T}_{11}$ & 8.36 & 8.23 & 8.19 & 8.26 \\
\hline
\end{tabular}

\section{Flavour (out of 9 points)}

Data on sensory evaluation in respect of Flavour value have been depicted in Table 7. Observations revealed that, at initial stage organoleptic quality status in respect of flavour of blended jam, the maximum flavour score value was found in $\mathrm{T}_{11}$ combination of blended jam (8.50) (banana fruit: pseudostem central core 100:00) followed by $\mathrm{T}_{10}$ (7.96) (banana fruit: pseudostem central core 90:10). However, $\mathrm{T}_{1}$ combination of blended jam, recorded lowest (6.06) (banana fruit: pseudostem central core 00:100) flavour score followed by $\mathrm{T}_{2}$ (6.21) (banana fruit: pseudostem central core 10:90).

At 3 month storage, maximum flavour score value was observed in $T_{11}$ combination of blended jam (8.32) followed by treatment $\mathrm{T}_{10}(7.80)$. However, the lowest flavour score was recorded in $T_{1}$ (6.00) followed by $T_{2}$ (6.14). The treatment $T_{11}$ combination of blended jam revealed the maximum flavour score (8.27), which was followed by $\mathrm{T}_{10}$ (7.79). However, the lowest flavour score was recorded in $T_{1}$ (5.98) followed by $\mathrm{T}_{2}$ (6.06) during 6th month of storage. The maximum flavour acceptability score mean value was found in $\mathrm{T}_{11}(8.36)$ combination followed by $\mathrm{T}_{10}$ (7.86). It decreased during 6 months of storage period. While the minimum score mean value was found in $\mathrm{T}_{1}$ (6.01) combination followed by $\mathrm{T}_{2}$ (6.14).

The maximum flavour score was obtained in $T_{11}$ which may be due maximum proportion of banana pulp and pleasant flavour with distinct aroma which was preferred more by panelists. Lowest flavour was found in $T_{1}$ due to low proportion of banana pulp. The flavour score of the product was decreased significantly during storage up to 6 months. This decreased in flavour score might be due to the loss of highly volatile aromatic compound during storage which is very sensitive to high temperature. It may also due to enzymatic degradation of phenols and an oxidative change of sugars was take place which was responsible for loss of flavour during storage. However flavour score was found acceptable i.e. above 7.00 up to blending of $50 \%$ pseudostem central core pulp with $50 \%$ banana pulp. These findings were in accordance with results obtained by Badal et al. (2006) in mixed fruit jam from strawberry, banana and mulberry, Deep Shika Sharma (2014) [9] in mango-jamun blended jam. Similarly Shah et al. (2015) ${ }^{[13]}$ observed decreased trend in flavour score in apple-olive blended jam. Anon., (2015) also found the similar results in pseudostem central core jam.

Table 7: Effect of banana fruit and pseudostem central core blended jam on texture during storage

\begin{tabular}{|c|c|c|c|c|}
\hline \multirow{2}{*}{ Treatments } & \multicolumn{3}{|c|}{ Storage periods (P) } & \multirow{2}{*}{ Mean (T) } \\
\cline { 2 - 4 } & $\mathbf{P}_{\mathbf{1}}$ (Initial) & $\mathbf{P}_{\mathbf{2}}$ (3 month) & $\mathbf{P}_{\mathbf{3}}$ (6 month) & \\
\hline $\mathrm{T}_{1}$ & 6.39 & 6.31 & 6.29 & 6.33 \\
\hline $\mathrm{T}_{2}$ & 6.58 & 6.43 & 6.41 & 6.47 \\
\hline $\mathrm{T}_{3}$ & 6.74 & 6.69 & 6.53 & 6.65 \\
\hline $\mathrm{T}_{4}$ & 6.87 & 6.81 & 6.79 & 6.82 \\
\hline $\mathrm{T}_{5}$ & 6.98 & 6.86 & 6.83 & 6.89 \\
\hline $\mathrm{T}_{6}$ & 7.32 & 7.30 & 7.26 & 7.29 \\
\hline $\mathrm{T}_{7}$ & 7.56 & 7.49 & 7.46 & 7.50 \\
\hline $\mathrm{T}_{8}$ & 7.68 & 7.62 & 7.59 & 7.63 \\
\hline $\mathrm{T}_{9}$ & 7.89 & 7.76 & 7.68 & 7.78 \\
\hline $\mathrm{T}_{10}$ & 8.01 & 8.00 & 7.98 & 8.00 \\
\hline $\mathrm{T}_{11}$ & 8.36 & 8.23 & 8.19 & 8.26 \\
\hline
\end{tabular}

\section{Overall acceptability (Average of colour, texture, taste and flavour)}

Data regarding the changes in overall acceptability of banana fruit and pseudostem blended jam was influenced by various treatments during the storage have been presented in Table 8. Moreover, it was found decreasing trend during storage. Observations revealed that, at initial stage organoleptic quality status in respect of overall acceptability status in respect of blended jam, the maximum acceptability was found in the treatment $\mathrm{T}_{11}$ (8.32) (banana fruit: pseudostem central core 100:00) followed by $\mathrm{T}_{10}(8.00)$ (banana fruit: pseudostem central core 90:10). However, $\mathrm{T}_{1}$ combination of blended jam recorded lowest overall acceptability score (6.33) (banana fruit: pseudostem central core 00:100) followed by treatment $\mathrm{T}_{2}$ (6.51) (banana fruit: pseudostem central core 10:90).

At 3 month storage, maximum overall acceptability score was observed in the treatment $\mathrm{T}_{11}$ combination of blended jam (8.21) followed by $\mathrm{T}_{10}$ (7.88). However, the lowest was 
observed in the treatment $\mathrm{T}_{1}$ (6.23) followed by $\mathrm{T}_{2}$ (6.44). The treatment $\mathrm{T}_{11}$ combination of blended jam recorded the maximum overall acceptability score (8.17) followed by the treatment $\mathrm{T}_{10}(7.82)$. Lowest overall acceptability score was recorded in the treatment $T_{1}(6.19)$ followed by $T_{2}(6.35)$ during 6 th month of storage.

In general from the mean data presented in the Table 8, the maximum overall acceptability score value was found in the treatment $\mathrm{T}_{11}$ (8.23) followed by $\mathrm{T}_{10}(7.90)$. The minimum overall acceptability score value was recorded in the treatment $\mathrm{T}_{1}$ (6.25) followed by $\mathrm{T}_{2}$ (6.43). It showed decreasing trend during 6 months of storage period.

During storage period overall acceptability score was decreased slightly due to decline in colour, texture, taste and flavour score. However, overall acceptability was found acceptable i.e. above 7.00 up to blending of $50 \%$ pseudostem central core pulp with $50 \%$ banana pulp. These findings were in accordance with results obtained by Badal et al. (2006) in mixed fruit jam from strawberry, banana and mulberry, Deep Shika Sharma (2014) [9] in mango-jamun blended jam. Similarly Shah et al. (2015) ${ }^{[13]}$ observed decreased trend in overall acceptability score in apple-olive blended jam. Anon., $(2015)^{[4]}$ also found the similar results in pseudostem central core jam.

Table 8: Effect of banana fruit and pseudostem central core blended jam on overall acceptability during storage.

\begin{tabular}{|c|c|c|c|c|}
\hline \multirow{2}{*}{ Treatments } & \multicolumn{3}{|c|}{ Storage period (P) } & \multirow{2}{*}{ Mean (T) } \\
\cline { 2 - 4 } & $\mathbf{P}_{\mathbf{1}}$ (Initial) & $\mathbf{P}_{\mathbf{2}}$ (3 month) & $\mathbf{P}_{\mathbf{3}}$ (6 month) & \\
\hline $\mathrm{T}_{1}$ & 6.33 & 6.23 & 6.19 & 6.25 \\
\hline $\mathrm{T}_{2}$ & 6.51 & 6.44 & 6.35 & 6.43 \\
\hline $\mathrm{T}_{3}$ & 6.65 & 6.56 & 6.47 & 6.56 \\
\hline $\mathrm{T}_{4}$ & 6.75 & 6.68 & 6.65 & 6.69 \\
\hline $\mathrm{T}_{5}$ & 6.86 & 6.77 & 6.70 & 6.78 \\
\hline $\mathrm{T}_{6}$ & 7.23 & 7.20 & 7.17 & 7.20 \\
\hline $\mathrm{T}_{7}$ & 7.39 & 7.32 & 7.27 & 7.33 \\
\hline $\mathrm{T}_{8}$ & 7.59 & 7.50 & 7.44 & 7.51 \\
\hline $\mathrm{T}_{9}$ & 7.75 & 7.64 & 7.56 & 7.65 \\
\hline $\mathrm{T}_{10}$ & 8.00 & 7.88 & 7.82 & 7.90 \\
\hline $\mathrm{T}_{11}$ & 8.32 & 8.21 & 8.17 & 8.23 \\
\hline
\end{tabular}

\section{References}

1. Radha T, Mathew L. Fruit crops. Published by New India Publishing Company 2007.

2. Nakirya M. The value of banana fruit 2007. (www.en.wordpress.com/tag/local-content)

3. Chundawat BS, Sen NL. Principles of fruit culture. Published by Agrotech publishing Academy, Udaipur 2002, 15-16.

4. Anonymous. Standardization of technology for processing of Banana central core jam. AGRESCO Report N.A.U., NAVSARI 2015, 07-25.

5. Anonymous. NHB. Database -2017.

6. Salunke DK, Desai BB. Banana and plantain. Postharvest Biotech. Fruits 1984;1:43-57.

7. Shakir I, Durrani Y, Hussain I, Mabood Qazi I, Zeb A. Physicochemical analysis of apple and pear mixed fruit jam prepared from varieties grown in Azad Jammu and Kashmir. Pakistan J Nutri 2008;7(1):177-80.

8. Chanbisana C, Banik AK. Studies on preparation of jam from ripe banana. Prog. Hort 2014;46(2):377-379.

9. Deep SS. Quality evaluation and storage stability of jamun mango blended jam. The Bioscan 2014;9(3):953957.
10. Vikram B, Bihari M, Narayan S, Prasad VM. Effect of dried powder of herbals addition on aonla jam with granulated particles of coconut. Inter. J Proc. Post Harvest Technol 2012;3(2):188-193.

11. Haqa R, Darakshanb M. Quality and Storage Stability of Developed Dried Apricot-Date Jam. J. Fd. Product Development and Pack 2014;1(3):37- 41.

12. Badal J. Goyal RK, Godara AK. Studies on storage of mixed jam from strawberry, banana and mulberry. Haryana J Hort. Sci 2006;35(3/4):239-241.

13. Shah W, Khan A, Zeb A, Khan MA, Shah FN, Amin NU. Quality evaluati on and preparation of apple and olive fruit blended jam. Global J Medical Res 2015;15(1):167172.

14. Patel NV, Naik AG. Studies on standardization of pulp proportion for banana - pineapple blended jam during storage. Inter. J Processing and Post Harvest Tech 2013;4(2):63-69.

15. Darakshanb M, Haqa R. Quality and Storage Stability of Developed Dried Apricot-Date Jam. J Fd. Product Development and Pack 2014;1(3):37-41. 